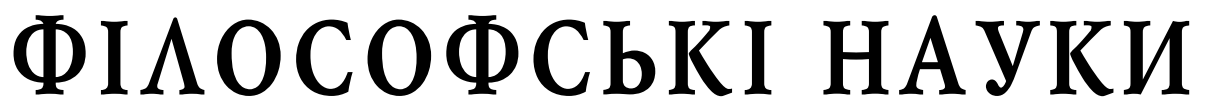

\author{
DOI: https://doi.org/10.32839/2304-5809/2021-11-99-31 \\ УДК 371.01(06)
}

Гавриш К.О., Шпачинський І.Л.

Миколаївський національний університет імені В.О. Сухомлинського

\section{ФІЛОСОФСЬКІ АСПЕКТИ ДИДАКТИЧНОЇ СИСТЕМИ ВАСИЛЯ ОЛЕКСАНДРОВИЧА СУХОМЛИНСЬКОГО}

\begin{abstract}
Анотація. У статті розкриваються нові аспекти фрілософських основ становлення і розвитку дидактичних граней педагогічної системи В. Сухомлинського, виділено особливості трактування ним гуманістичної та гуманітарної фрілософії, окреслено відповідний зміст педагогічних поглядів, лінгвістичні, ціннісні, метафрізичні та епістемологічні основи організащії шкільної освітньої системи, розкрито суть чотирьох фрілософських позицій В. Сухомлинського, які, на наш погляд, виступили в якості базових у побудові дидактичної системи Павлиської середньої школи. Кожна освітня концепція описуе відповідні методи та інструменти, що поліпшують процес переходу від мислення в образах до використання концептуальних засобів, а потім до формування концептуального мислення учнів. В. Сухомлинський скеровуе їх на цілеспрямоване логічне перетворення шляхом пошуку необхідного значення у відомих об’єктах та природних явищах. Даний спосіб, на наш погляд, допомагає відкрити для дитячої свідомості нові можливості, приховані поза межами емпіричної теорії пізнання.
\end{abstract}

Ключові слова: Василь Олександрович Сухомлинський, фрілософрські аспекти, дидактична система, Павлиська середня школа, загальна середня освіта, учні загальної середньої школи.

Havrysh Kateryna, Shpachynskyi Ihor V.O. Sukhomlynskyi Mykolaiv National University

\section{PHILOSOPHICAL ASPECTS OF VASYL OLEXANDROVYCH SUKHOMLYNSKY'S DIDACTIC SYSTEM}

Summary. The article reveals the philosophical foundations of the formation and development of didactic facets of V. Sukhomlinsky's pedagogical system, highlights the peculiarities of his interpretation of humanistic and humanitarian philosophy, outlines the content of pedagogical views, linguistic, value, metaphysical and epistemological foundations of school education, and reveals philosophical V. Sukhomlynsky, who, in our opinion, acted as a basis for building a didactic system of Pavlyska secondary school. Each educational concept describes appropriate methods and tools that improve the process of transition from thinking in images to the use of conceptual tools, and then to the formation of conceptual thinking of students. V. Sukhomlinsky directs them to a purposeful logical transformation by finding the necessary meaning in known objects and natural phenomena. This method helps to open new possibilities for children's consciousness, hidden outside the empirical theory of cognition. The historical and pedagogical heritage of the scientist and teacher of the second half of the XX century Vasyl Oleksandrovych Sukhomlynsky is a source of preservation, dissemination and development of pedagogical knowledge, which ensures the historical relationship of generations. The world-famous teacher, director of Pavlyska Secondary School, scientist and author of pedagogical research, distinguished among others such professional qualities as: culture of pedagogical work, recognition of priority of universal values, flexible type of thinking, depth of methodological knowledge as the main tool of theoretical and practical activities. The author found that V. Sukhomlinsky created an original holistic pedagogical system based on an anthropological approach, harmonization of humanistically oriented forms, means and methods of pedagogical activity, its subject-subject nature and recognition of the child's personality as the highest educational value. and educational processes. Vasyl Oleksandrovych interpreted the educational process as the realization of the innate properties, spontaneous impulses and reactions inherent in the student. At the same time, he attached great importance to the specially organized educational influence of society.

Keywords: Vasyl Oleksandrovych Sukhomlynsky, philosophical aspects, didactic system, Pavlyska secondary school, general secondary education, students of general secondary school.

Постановка проблеми. Актуальність те-

1 матики дослідження обумовлена орієнтаціею сучасних соціальних процесів на цілісні уявлення про людину, як соціальну та суспільну істоту, їі внутрішній світ, символізований у різноманітних формах людської діяльності. Проблема всебічного розвитку людської особистості цікавила дослідників усіх часів, але особливо гостро вона стоїть перед сучасним суспільством.

Гуманістична спрямованість є домінуючою тенденцією сучасної освіти протягом останніх де- сятиліть, а принцип наступності - основною передумовою її успішного розвитку.

Теоретичним піді́рунтям гуманістичної спрямованості сучасних освітніх процесів виступае антропологічний підхід, який визначає в педагогіщі нову методологію, теорію та практику, в основі яких лежать уявлення про людину (побудова взаємовідносин на довірі до іїі природи, потенщійно великих можливостей ії розвитку та особистого досвіду).

Широко відомі фракти біографрії В. Сухомлинського, його «крилаті» висловлювання, матеріали архівів та службова документація надають 
можливість стверджувати, що особистість В. Сухомлинського та значення фрілософрських аспектів його педагогічних ідей не були досі оцінені нами належним чином.

Педагогічна антропологія В. О. Сухомлинського розглядаеться нами як авторська педагогічна система, перевірена багаторічним практичним досвідом, яка протиставляе технократичному суспільству гуманістичну орієнтащію, що оголошує «людину найвищою цінністю на Землі». Засобами своєї педагогіки видатний вчений намагався вирішити глобальні проблеми цивілізації в контексті взаємодії«людина-світ», «людина-суспільство», «людина-природа», «людина-людина». Даний антропологічний підхід до виховного процесу відображає віру в загальнолюдські цінності, неповторність людської індивідуальності, талановитість та самобутність кожної особистості. Сьогодні розвиток творчості видатного педагога в педагогічній теорії та практищі, з урахуванням фрілософрських аспектів, необхідно вивести на новий рівень.

Аналіз останніх досліджень і публікацій. Вивченню унікальної спадщини В. Сухомлинського присвячено величезну кількість робіт вітчизняних науковців: Ю. Азарова, В. Антонця, С. Білецької, О. Борисовського, А. Гранкіна, К. Григор'єва, О. Дзеверіна, І. Зязюна, О. Іванчикової, М. Любіциної, Г. Мединського, М. Мухіна, Є. Родчаніна, С. Соловейчика, О. Сухомлинської, Б. Тартаковського, Г. Туюкіної та міжнародних дослідників: у Австралії - А. Кокерель; у Болгарії - С. Тодоров, Л. Мілков; в Угорщині - А. Петрікаш; у Німеччині - Г. Веттштед, У. Гріш, Е. Гюнтер, Ю. Полцін, Р. Штайнік; у Росії - Ю. Руденко, Т. Челпаченко; у Китаї - Бі Шу-джі, Ван І-гао, Тан-Чі-ці; у Польщі - М. Библюк; в Японії - Т. Ідзюін та ін.

Свідченням того, що фрілософрські питання виховання і освіти займають чільне місце в творах В. Сухомлинського є попередній досвід фрілософрського аналізу поглядів павлиського вченого. Науковцями минулого та сучасними дослідниками було різнопланово досліджено такі аспекти означеної проблеми, як: гуманістичні традиції та новаторські ідеї в педагогіці В. Сухомлинського (М. Мухін); світоглядна спрямованість навчання в педагогічній спадщині В.О. Сухомлинського (О. Невмержицький); особливості використання В. Сухомлинським досвіду теорії всебічного та гармонійного розвитку особистості (А. Кузнецов); витоки фрілософсько-педагогічних поглядів В. Сухомлинського (І. Зязюн, Є. Родчанін).

Виділення невирішених раніше частин загальної проблеми. Тепер, коли освітній сектор країни вирішуе стратегічне завдання модернізації змісту загальної та професійної освіти, ідеї і практичний досвід видатного педагога, можуть зіграти свою продуктивну роль. Про підвищену увагу до спадщини павлиського педагога свідчить той фракт, що різні аспекти його діяльності висвітлені науково-методичній літературі та періодичних виданнях вітчизняних та зарубіжних дослідників минулого та сучасності. Однак, варто відзначити, що в проаналізованих дослідженнях, на наш погляд, не достатньо розкрито проблему систематизації фрілософрських аспектів дидактичної системи В. Сухомлинського.

Недостатній розвиток даного напряму досліджень та потреба сучасної педагогічної науки у систематизащї уявлень про природу та сутність виховання людини обумовили потребу у розгляді педагогічної спадщини В. Сухомлинського як вченого-фрілософра, який зумів обгрунтувати необхідність зв'язку природи із людською сутністю та природою їі виховання.

Мета статті - розкрити нові аспекти фрілософських основ становлення і розвитку дидактичних граней педагогічної системи В. Сухомлинського, виділити особливості інтерпретащії видатним вченим гуманістичних та гуманітарних фрілософрських аспектів, окреслити його педагогічні погляди на організацію концептуальних засад дидактичної системи шкільної освіти.

Виклад основного матеріалу. Як відомо, фрілософрське розуміння природи знань є основою людського світогляду, тому саме воно визначає принщипи та дидактичні положення, що були реалізовані у своїй дидактичній системі В. Сухомлинським. Будучи не тільки педагогом, а й керівником педагогічного колективу Павлиської середньої школи, він розмірковував над найбільш важливими фрілософськими проблемами, переосмислював та по-своєму інтерпретував їх. Відомо, що до переліку питань, що хвилювали його як вченого та публіџиста входили: антропологічні, аксіологічні, онтологічні, гносеологічні основи дидактичної системи школи. Філософрські погляди В. Сухомлинського розкриті ним у книгах «Серце віддаю дітям», «Народження громадянина», «Як виховати справжню людину», охоплюють 3 одного боку - сутнісні, а 3 іншого - універсальні поняття фрілосодрї (ставлення людини до природи; взаємозв'язок категорій «добро» та «зло»; етика та загальнолюдські моральні норми; сенс життя та смерті; поняття «щастя» та «свобода»; категорї трагічного, прекрасного, піднесеного та потворного).

В процесі дослідження нами було встановлено, що наукові роботи В. Сухомлинського, вважаємо, спрямовані на всебічний аналіз таких фрілософрських проблем, як:

- взаємозалежність інтелектуального розвитку та природи людського розуму;

- розуміння навколишнього світу в процесі занурення в гармонію природи (уроки мислення, уроки на природі);

- усвідомлення взаємозв'язку різноманітних видів діяльності людини (розумову, фрізичну, духовну працю).

Понад два десятки років вчений переосмислював й практично перевіряв власні фрілософрсько-світоглядні установки, що згодом втілились у стійких теоретичних позищіях та зрілих переконаннях. Основними фракторами, що визначили феномен дидактичної системи В. Сухомлинського виступили: методична та гуманістична спрямованість, а також філософрсько-педагогічна культура керівника.

Незважаючи на те, що В. Сухомлинський не акцентував увагу на фрілософрьких ідеях власних робіт, його дидактична система побудована на матеріалістичній dpiлософpiï, яка органічно увійшла до контексту його педагогічних досліджень. Він володів унікальним даром, простими, образними словами висловлювати думки, що передають неоднозначність, суперечливість та глибину інтелектуальних, духовно-моральних, етичних та естетичних фрілософрських позицій. «В. Сухомлинського вирізняе особливий стиль та творчий 
підхід до відбиття фрілософрських узагальнень в процесі описування педагогічних явищ. Створюючи твори такого роду педагог повинен мати не тільки глибоку гуманістичну спрямованість особистості, а й високий рівень освіченості, виняткову культуру мислення, володіти усім обсягом передових фрілософоських ідей» [1, с. 98].

Філософрською базою дидактичних поглядів В. Сухомлинського було гуманістичне спрямування в педагогіці. Гуманістична освітня парадигма визнає абсолютний пріоритет людського права на свободу виявлення та розвитку здібностей, в тому числі й інтелектуальних.

Розглянемо основні фрілософрські позиції В. Сухомлинського, що, на нашу думку, є базисними у побудові дидактичної системи Павлиської середньої школи.

Перша позиція відображає «ставлення до людської природи». Сутнісні основи розуміння В. Сухомлинським даної фрілософрської позиції полягають в глибокому переконанні, що «знання про людину як індивідуума, про їі внутрішній світ, про самобутне світосприйняття себе та всього, що відбувається навколо неї є невід'ємною частиною цілісної наукової картини світу, за відсутності якої - повноцінна людина сдормуватися не може». "Справжня людина - це людський дух, який виявляеться в переконаннях та почуттях, волі та прагненнях, у ставленні до людей і до самої себе, в здатності любити та ненавидіти, бачити у мрії ідеал та боротись за нього» [5, с. 19].

Другою базовою фрілософрською позищією видатного вченого, на наш погляд, $є$ усвідомлення однієї з таких основних людських потреб, як «потреба в пізнанні довкілля». Особливо яскраво вона виражена у дітей раннього віку. У складній ієрархії потреб, на думку В. Сухомлинського, потреба в пізнанні стоїть відокремлено. Як учитель, одним iз найважливіших завдань навчання, В. Сухомлинський вважав постійне стимулювання та підтримання дитячої допитливості, бажання дітей дізнатися нове, цікаве. В результаті багаторічних творчих пошуків, педагогом було систематизовано спещіальні методи та прийоми, що можуть стати потужним стимулом пізнання, сприятимуть формуванню та розвитку інтересу до навчання (стимулювання творчих запитань, пошук вузликів знань, побудова ланщюжка думки тощо).

Так, у книзі «Розмова 3 молодим директором школи» 1973 року вчений пише: «..досвідчені вчителі практично реалізують класичне правило Аристотеля - мислення починається 3 подиву... Чому це так відбувається? Почуття подиву - могутне джерело бажання знати» [3, с. 442].

Почуття, які викликає процес пізнання, відображають сутність основних потреб сучасної людини. «Вчення, оволодіння знаннями, сидіння за книгою - велике благо та щастя. Знання лише тоді стають благом, коли вони народжуються зі злиття внутрішніх духовних сил людини та світу, який пізнається. Найважливіше джерело радощів пізнання - ...переживання та відчуття того, що знання - це плоди напруження мого людського духу, плоди пошуку, творчості - праці думки, душі» [4, с. 78-79].

Як вважається, третя позищія, що надає dpiлософський зміст дидактичній системі В. Сухомлинського, - творчий початок думки. Аналіз змістовного компонента пізнавальних потреб особистості дозволив В. Сухомлинському серйозно підійти до проблеми фрормування людської здатності до творчості, що базується на вільній розумовій діяльності. Надання розумовій праці учня творчого характеру сприяе фрормуванню позитивного емоційного стану, що задовольняе духовні потреби особистості. «Будь мислителем. Живи в світі думок, осягай ідеї. Жити без думки - це все одно, що вести жалюгідне існування. День без думки, без читання - марно прожитий день. Марнотратство часу - марнотратство безцінних багатств людського життя» $[4$, с. 96].

Четверта фрілософрська позиція дидактичної системи В. Сухомлинського, на наш погляд, дозволяе виділити аксіологічні аспекти педагогічного знання. Педагог зробив акцент на потреби людини в особистісному самовдосконаленні в процесі освітньої діяльності. Власне розуміння ролі розумової праці було перенесено вченим в область дидактики наступним чином: «Від нас... величезною мірою залежить, щоб маленьке дитя стало мислителем, який розуміє й переживає величне людське право на життя, щастя та радість... Дана сорера духовного життя потребує найбільшого такту, глибокої поваги до людського права на щастя» [4, с. 22].

Пошук відповідей на життево важливі питання спонукали В. Сухомлинського до дослідження етичних та естетичних проблем освіти. Так, для вченого поняття «життя» та «смерть», «пам'ять» та «забуття», «трагедія» та «краса» були основним предметом усіх наукових досліджень. Процес долання смерті у фрілософрiї та педагогіці вченого являє собою «символічне безсмертя результатів людської творчості». Постійним прагненням педагога було: «щоб розуміння життя та смерті, почуттів та переживань близьких дитині людей, сприяло її дорослішанню, зрілості життевих поглядів та суджень, вихованню вміння цінувати людську особистість, усвідомленню 㣙 як найбільшої цінності. «Розуміння людиною етичних аспектів взаємозв'язку між життям та смертю $€$ найважливішою умовою формування оптимістичного світогляду, життелюбності та життерадісності, вміння цінувати й дорожити власним життям та життям оточуючих. Багаторічний досвід роботи в галузі освіти переконав мене, що дитина переживаючи смерть разом із дорослими ставиться до неї як до невідворотного горя, але водночас із цим черпає у дорослих оптимістичну віру в непереможність життя» [2, с. 260].

По-справжньому моральна особистість не може формуватися без прагнення до прекрасного. Пізнання прекрасного, переживання радості, пов'язане 3 його створенням, з'єднуе моральну чистоту із мораллю, етику з естетикою. Як видно 3 висловлювань В. Сухомлинського, різноманітними проявами прекрасного, що розкривають справжній зміст людського існування, він вважав: явища природи, основи людської духовності, любов, істину, нічим не обмежене виявлення доброти, здатність відчувати та розуміти, здатність творити, діяння та пізнання. Пізнання прекрасного надзвичайно важливе для формування світогляду, що грунтується не тільки на сумі знань, але і на морально-естетичному, емоційному світі людини, в тому числі і на «почутті прекрасного». 
«Прекрасне» трактується у фрілософріi, як найважливіше поняття естетики, що характеризуе властивості явищ, природи, суспільного життя, людської діяльності, які здатні викликати в людині безкорисне кохання, почуття радості та відчуття свободи.

«Прекрасне» виражає не особистісно-споживчу, а суспільно-практичну цінність явищ, їх духовне значення для людини. Відтак, можна стверджувати, що вже у той період застосовувався глибоко продуманий особистісно-оріентований підхід.

«Основна мета навчання, - на думку В. Сухомлинського, - дати відчути учневі щастя та радість розумової праці, одухотворити його благородними почуттями» [3, с. 208].

В. Сухомлинський у своїх педагогічних працях розглянув основні питання етики і запропонував шляхи формування у підростаючого покоління правильного розуміння життевих, особистісно та суспільно значущих цілей, потреб, інтересів та прагнень. У структуру дидактичної системи ним були органічно включені категорії етики та естетики, поняття «добро» та «зло», «обов'язок», «гідність", «честь», «совість», «свобода», «відповідальність», «громадянськість», «любов", «життя» та «смерть». Проаналізувавши дані поняття, він розкрив суть та зміст їхнього значення для вирішення проблем інтелектуального, трудового, морального, етичного, естетичного, фpiзичного виховання. Власної педагогічною діяльністю, результати якої відображені в численних творах, В. Сухомлинський довів, що сенс життя в самому житті, в його правильному розумінні, організації та діалектичному взаємозв’язку.

Так, на основі аналізу наукових джерел нами було встановлено, що духовний діалог педагога із учнями у спадщині В. Сухомлинського $є$ найбільш складною формою взаємодії, потребує більш детального розгляду та практичної реалізації. У зв'язку із цим на базі початкових класів загальноосвітньої школи нами було проведено експериментальне дослідження, спрямоване на формування ключових компетентностей учнів початкової школи, серед яких, зокрема, чільне місце посідали саме соціальні (вільне володіння державною мовою, здатність спілкуватися рідною (у разі відмінності від державної) та іноземними мовами, інноваційність, екологічна компетентність, навчання впродовж життя, власне громадянські та соціальні компетентності, культурна компетентність) в контексті дидактичної системи В. Сухомлинського. До експерименту було залучено два других класи (по 28 учнів у кожному), і відповідно - їх класних керівників.

Духовне спілкування відповідно до положень педагогічної системи В. Сухомлинського передбачало комплексний розвиток гносеологічної, аксіологічної, комунікативної та творчої сырер учнів початкової школи. У духовному спілкуванні педагога із учнями у єдності виступали пізнання, вироблення цінностей та творчість. Відмінною рисою діалогів була інтеграція теоретичного (логічного, понятійного) та емоційного ставлення учнів до явищ навколишнього світу, що обговорювались. Явища та події усвідомлювались учнями не тільки на понятійному, а й на емоційному рівні. Вони виявляли особистісне ставлення та власні почуття до об'екту (предмету) діалогу.
Для 28 учнів другого класу нами було створено спеціальне просторово-матеріальне середовище, що передбачало такі місця проведення виховних діалогів, як: природне довкілля та класна кімната (яка за потреби перетворювалась на «кімнату казок», «кімнату роздумів», «куточок мрійника», «садок здоров'я», "зелену класну кімнату», «садок героїв» тощо).

В процесі освітньої діяльності педагог (класний керівник) не лише використовував прийоми спонукання учнів до виховного діалогу та рефлексії через художні образи оповідань, казок, притч, билин та художніх мініатюр, а й забезпечував емоційно сприятливий для діалогу фон, що підтримував високий рівень працездатності учнів.

Нами було виділено чотири основні групи педагогічних умов діалогічності навчально-виховного процесу. Розглянемо їх в таблиці 1, яку розроблено автором.

Наведені групи педагогічних умов, вважаємо, взаємодоповнюють одна одну та в комплексі спрямовані на забезпечення актуальної для сучасної практики початкової освіти, зокрема діалогічності навчально-виховного процесу.

Експериментальне навчання відбувалось за трьома послідовними етапами: інформаційноознайомлювальний (інформування щодо норм сформованості ключових компетентностей учнів початкової школи, консультування сімей стосовно особливостей їх фрормування в контексті дидактичної системи В. Сухомлинського), теоретично-практичний (підвищення педагогічної культури педагогів та батьків учнів), оцінно-корегуючий (реалізація педагогічних умов діалогічності навчально-виховного процесу).

Едективність проведеного експериментального дослідження виявилась на контрольному етапі експерименту. Порівняльні дані, засвідчили суттєве підвищення рівня сформованості ключових компетентностей учнів початкової школи за гносеологічною, аксіологічною, комунікативною та творчою сферами (див. таблицю 2).

Так, на високому рівні кількість учнів експериментального класу збільшилась із 20\% до $72 \%$. Відповідно зменшилася кількість учнів на середньому - із 35\% до $18 \%$ і низькому рівні - із $45 \%$ до $10 \%$ учнів. Зазначимо, що у контрольному класі також відбулись певні позитивні зміни, проте несистематичність та низька варіативність форм роботи значно знизили можливість наближення учнів другого класу до вищого рівня сфрормованості ключових компетентностей. Так, дещо збільшилася кількість учнів на високому - $322 \%$ до $46 \%$. Відповідно зменшилася кількість учнів на середньому рівні - із 40\% до $34 \%$ і низькому рівні - із $38 \%$ до 20\% учнів. Це закономірні вікові зміни, що відбулись у процесі навчання за традиційною методикою. Розглянемо графрічне порівняння більш детально у рисунку 1.

Проведений моніторинг свідчить про успішну реалізацію принципу взаємодії всіх суб'єктів виховного процесу: педагогів, вихованців та їхніх батьків. Так, зворотний зв'язок у системі взаємовідносин педагог-учні, педагог-батьки, педагог-педагог сприяв підвищенню рівня контролю за перебігом освітнього процесу та його відкритістю для учасників. Таке впровадження дидактичної системи В. Сухомлинського у практику сучасної шкільної освіти, вва- 
Педагогічні умови діалогічності навчально-виховного процесу

\begin{tabular}{|c|c|}
\hline Група & Зміст \\
\hline $\begin{array}{l}\text { Герменевтичні умови були спрямовані на } \\
\text { поглиблене всебічне вивчення, усвідомлення } \\
\text { педагогом чинників, що забезпечують } \\
\text { діалогічність навчально-виховного процесу. }\end{array}$ & $\begin{array}{l}\text { - вивчення педагогом особистості учня; } \\
\text { - прагнення педагога до дослідницької позиції; } \\
\text { - дослідження «дитинства» як педагогічного феномена. }\end{array}$ \\
\hline $\begin{array}{l}\text { Особистісно-педагогічні умови передбачали } \\
\text { опору на особистісну сферу суб’єктів } \\
\text { навчально-виховного процесу. }\end{array}$ & $\begin{array}{l}\text { - встановлення між педагогом та учнями взаємно довірчих } \\
\text { відносин; } \\
\text { - індивідуалізація навчально-виховного процесу; } \\
\text { - стимулювання прагнення учня до морального ідеалу; } \\
\text { - співпраця педагога з учнями. }\end{array}$ \\
\hline $\begin{array}{l}\text { Комунікативні умови були спрямовані на } \\
\text { досягнення ефективної виховної взаємодії. }\end{array}$ & $\begin{array}{l}\text { - встановлення оптимальної дистанції у взаємовідносинах } \\
\text { педагог-учні; } \\
\text { - посилення емоційно-емпатійного напряму спілкування; } \\
\text { - забезпечення гармонійної взаємодії всіх суб'єктів } \\
\text { навчально-виховного процесу (педагогів, учнів, батьків), } \\
\text { здійснення своєчасного зворотного зв'язку між ними; } \\
\text { - моделювання для учнів зовнішніх та внутрішніх } \\
\text { мовленнєвих ситуацій. }\end{array}$ \\
\hline $\begin{array}{l}\text { Організаційно-педагогічні умови } \\
\text { відображали систему фракторів, пов’язаних } \\
\text { із плануванням та підготовкою бази для } \\
\text { навчально-виховної взаємодії. }\end{array}$ & $\begin{array}{l}\text { - створення діалогічного виховного середовища; } \\
\text { - організація педагогом духовного спілкування з учнями; } \\
\text { - планування видів діяльності учнів, спрямованих на } \\
\text { фромування у них самостійної пошукової активності; } \\
\text { - створення проблемних ситуацій; } \\
\text { - моделювання у педагогічному колективі наукового діалогу. }\end{array}$ \\
\hline
\end{tabular}

Порівняльні дані рівнів сформованості ключових компетентностей

\begin{tabular}{|c|c|c|c|c|c|c|}
\hline \multirow{3}{*}{ Групи } & \multicolumn{6}{|c|}{ Рівні сформованості \% } \\
\hline & \multicolumn{2}{|c|}{ B } & \multicolumn{2}{|c|}{$\mathbf{C}$} & \multicolumn{2}{|c|}{$\mathbf{H}$} \\
\hline & До навчання & $\begin{array}{c}\text { Після } \\
\text { навчання }\end{array}$ & До навчання & $\begin{array}{c}\text { Після } \\
\text { навчання }\end{array}$ & До навчання & $\begin{array}{c}\text { Після } \\
\text { навчання }\end{array}$ \\
\hline EК & 20 & 72 & 35 & 18 & 45 & 10 \\
\hline КК & 22 & 46 & 40 & 34 & 38 & 20 \\
\hline
\end{tabular}

жаємо, дозволило не лише забезпечити перехід від когнітивної моделі до щіннісно-смислової, а й гуманізувати відносини у системі педагог-учень-батьки.

Висновки і пропозиції. На підставі проведеної роботи, ми можемо констатувати, що у багаторічній педагогічній практиці В. Сухомлинський реалізовував найважливішу фрілософрську ідею: гуманну школу. Таким чином, наше дослідження розкриває не тільки базові аспекти окремих фрілософрсько-педагогічних питань, а й фріло- софрсько-світоглядну позищію видатного педагога в контексті його авторської дидактичної системи, що містить думки видатних фрілософів минулого та заслуговуе підвищеної уваги педагогічних працівників закладів загальної середньої освіти.

Подальші перспективи дослідження означеної проблеми ми розглядаємо у пошуку ефективних можливостей практичної реалізації фрілософрських аспектів дидактичної системи В. Сухомлинського у сучасних закладах загальної середньої освіти.

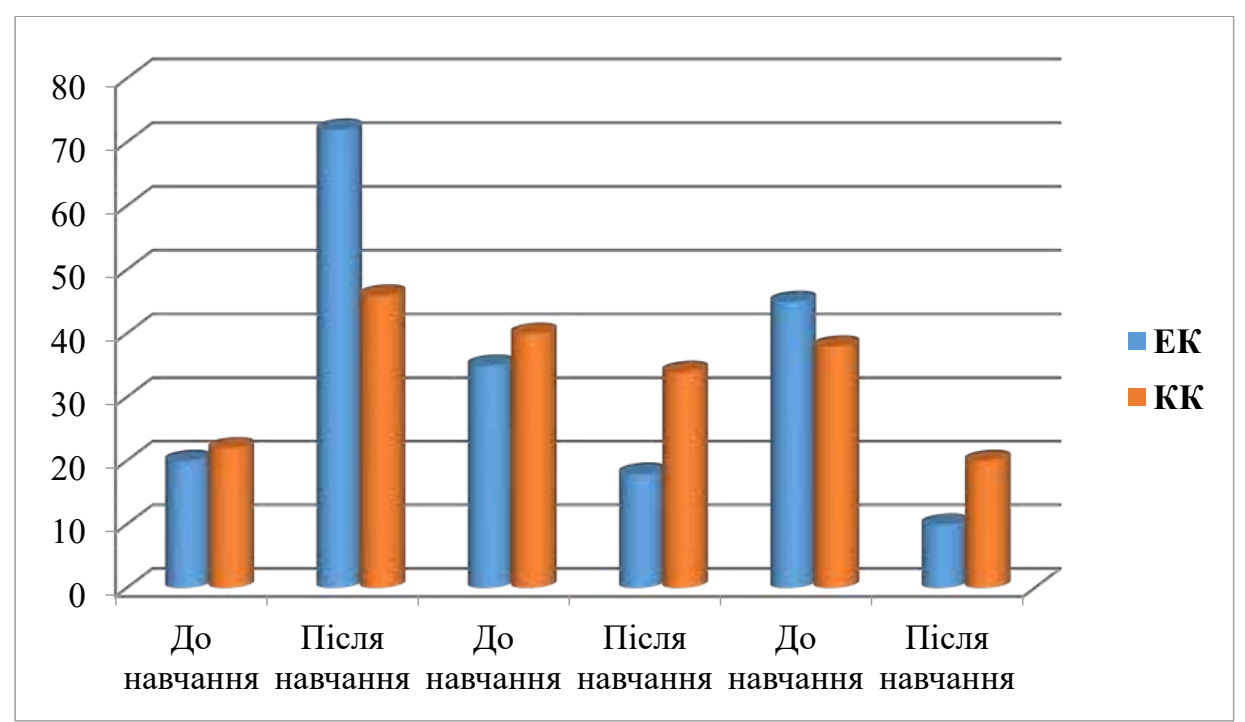

Рис. 1. Порівняльні дані рівнів сформованості ключових компетентностей 


\section{Список літератури:}

1. Руденко Ю.Д. Народная педагогика и В.А. Сухомлинский. Советская педагогика: ежелесячный научнотеоретический журнал. 1991. № 2. С. 103-106.

2. Сухомлинский В.А. Избранные произведения : В 5 томах. Киев, 1979. Т. 2. 718 с.

3. Сухомлинский В.А. Избранные произведения : В 5 томах. Киев, 1979. Т. 4.670 с.

4. Сухомлинский В.А. Как воспитать настоящего человека: Этика коммунистического воспитания. Москва, 1990. $288 \mathrm{c}$.

5. Сухомлинский В.А. Письма к сыну. Москва, 1979. 122 с.

\section{References:}

1. Rudenko Yu.D. (1991) Narodnaya pedahohika i V.A. Sukhomlynskyy [Folk pedagogy and V.A. Sukhomlinsky]. Soviet pedagogy, no. 2. pp. 103-106.

2. Sukhomlinsky V.A. (1979) Yzbrannye proyzvedenyya: V 5 tomakh [Selected works: In 5 volumes]. Kyiv: Radianska school, vol. 2. (in Russian)

3. Sukhomlinsky V.A. (1979) Yzbrannye proyzvedenyya: $V 5$ tomakh [Selected works: In 5 volumes]. Kyiv: Radianska school, vol. 4. (in Russian)

4. Sukhomlinsky V.A. (1990) Yak navchaty ts'oho lyudyny: Etyka komunistychnoho vykhovannya [How to bring up a real person: Ethics of communist upbringing]. Moscow: Pedagogics. (in Russian)

5. Sukhomlinsky V.A. (1979) Pys'ma k synu [Letters to son]. Moscow: Enlightenment. (in Russian) 